\title{
Ethical ways to increase donation of haematopoietic stem cells
}

\author{
Bernice Elgera, Laura Cabrera ${ }^{a}$ \\ a Institute of Biomedical Ethics, University of Basel
}

\begin{abstract}
German and French abstracts see p. 98
Ethical issues in the context of human biological material donation have been discussed for a long time, from organ donation to tissue and cell donation. One main ethical concern related to donation has to do with ways to increase donation in safe and ethical ways. In this paper we focus on ethical ways to increase donation in the context of unrelated haematopoietic stem cell donation, such as tailored information about risks and benefits, and non-monetary benefits. We also discuss whether current practices that are used for increasing donation are ethical or not, such as investing effort and resources for certain types of haematopoietic stem cell banks, payment for donation, advertising and directed donation. We conclude with some recommendations for moving forward the debate on this field and promoting ethical practices within the field of haematopoietic stem cell donation not only in the Swiss context but potentially applicable worldwide.
\end{abstract}

Keywords: medical ethics, donation, ethics, hematopoietic, stem cells.

\section{Introduction: \\ The need for haematopoietic stem cell donation}

Many haematological diseases are life-threatening and can only be cured if the patient undergoes transplantation of haematopoietic stem cells (HSC). In order to improve prognosis and to decrease risks, the degree of human leukocyte antigens (HLA) match between donor and recipient is very important. There are cases where it is not possible to find a donor residing in the same country for an affected patient waiting to receive HSC transplantation. Hence, in order to save lives, international collaboration between various donor registries from different countries is paramount.

The benefit of international cooperation is proven by the fact that in 2008, of the more than 11500 patients who received a haematological stem cell transplant from an unrelated donor internationally, more than $44 \%$ of those patients were treated using a stem cell donor or cord blood unit that came from a different country than the patient [1]. Regarding the Swiss context, around $95 \%$ of Swiss patients receive blood stem cells from a donor abroad, whereas about $90 \%$ of all Swiss donations go to patients abroad [2].

Unrelated HSC transplants can be obtained from cord blood banks or adult stem cell donor banks. At present, there are around 19.4 million registered unrelated donors worldwide, in 65 stem cell donor registries from 48 countries, and in 44 organisations of cord blood banks from 30 countries [3].

According to statistics from the Blood Marrow Donor Worldwide annual report the number of unrelated donors, stem cell donor registries and publicly stored cord blood units has been growing each year. However, the number of donors is still largely insufficient to cover the number of HSC transplants needed, in particular for patients who have a rare HLA type [1]. In relation to the Swiss context the need for finding more donors has been seen as a priority given that Switzerland is at the bottom of international rankings with just 2.8 donor per 1000 inhabitants [2]. Consequently, transplantations registries, physicians as well as donors and patient associations have all searched for strategies in order to increase the number and diversity of available stem cell transplants. In Switzerland the Swiss Transfusion SRC, division Swiss Blood Stem Cells (SBSC), is the national organisation for all matters relating to blood stem cells, from registration to search of suitable donors worldwide [2].

In the current article we will analyse from an ethical perspective different strategies to increase unrelated HSC donation and provide recommendations regarding their ethical acceptability. Direct donation to siblings will not be included since ethical issues are not completely the same as with unrelated donation. We will in particular examine (1) whether ethical arguments exist to invest efforts and resources in certain types of HSC banks rather than in others, and how different strategies may be used to increase donation, such as (2) tailored information about risks and benefits, (3) motivation enhancement strategies to donate, in particular avoiding last minute withdrawal of donors that puts at risk the life of the recipient, (4) advertising, (5) unrelated donation limited to certain groups of recipients, (6) payment for donation and (7) additional non-monetary benefits.

\section{Scarcity of donors and transplantable material: particularities of HSC donation in comparison with other types of tissue or organ donation}

Strategies to increase the quantity of material suitable for donation have been discussed in different contexts ranging from living or cadaver organ donation to various types of blood product donations. Even more than for other types of transplants, in HSC transplantation 
the specific match between donor and recipient is very important for prognosis. Another characteristic of HSC transplantation is that repeated donations may be needed to save the life of the patient. ${ }^{1}$ A particular aspect of this type of living donation is, that in the case of unrelated donation, there is a considerable time gap between the moment a donor agrees to be in a registry and the actual moment of donation [4]. On average a possible donor has been in the registry for 8 years [5] before he or she is approached because a matching patient has been found. This implies that donors may have signed up to be registered but have forgotten that they once agreed or changed their mind and either refused donation or refuse repeated donation. Strategies to increase donation have to take into account the particularities of HSC donation. They also have to take into account availability of resources, evidence, external regulations and, both donors and receivers expectations [6].

Ethical considerations related to increasing the number of donors and donated units are shaped by the different risks, inconveniences and benefits for donors. Risks for donors depend on of the type of the transplanted entity. HSC donation can be situated on a middle ground between blood donation and living organ donation, e.g. of a paired organ such as kidneys. Risks and inconveniences of HSC donations for donors are not as low as they are for blood donation. Indeed, HSC donation requires either minor surgery to obtain bone marrow, or the treatment of the donor with granulocyte colony stimulating factor (G-CSF) in order to be able to harvest enough stem cells from the peripheral blood (PB). The risks of G-CSF have so far not yet been fully determined, although short term risks seem to be rather low. On the other hand, living solid organ donation, e.g. kidney donation, has clearly more serious side effects than the donation of HSC because of the fact that the lacking organ will not regrow even if on the functional level a single kidney is sufficient to permit long term survival of the donor.

The words stem cells have a tendency to trigger high ethical awareness. It is therefore important to examine whether the fact that the transplant consists of stem cells creates particular concerns and distinguishes this form of transplantation from others. In this regard it is crucial to remind ourselves that most ethical concerns in the stem cell debate are related to human totipotent stem cells that may give rise to a human being. At present, it is not possible to reprogramme adult somatic stem cells into totipotent cells. As such we do not see any reason to treat the donation of HSC differently than the donation of other somatic cells. Nonetheless, if reprogramming of somatic cells became a reality, then, it is likely that this will create new ethical problems for various adult cell donations, not only HSC donation. In relation to the benefits for donors that might result from unrelated donation, it is difficult to say whether these are specific to the type of transplant or recipient.
If donors are motivated by intrinsic or extrinsic altruism [7], the «warm glow» could be higher in proportion of the taken risks as well as to the created benefit, similar to the fact that having risked one's own life to save another person from drowning might make the life-saver happier than having altruistically given one's sandwiches to a hungry beggar with the side effect of staying hungry oneself for the evening. It is also not excluded that some donors might feel happier if they knew that they have saved the life a young child as compared to saving the life of an eighty year-old adult. While the degree of benefit might influence willingness to donate, we will discuss later whether this has an influence on the ethical aspects of donations.

We conclude from the existing similarities between HSC donation as compared to other types of tissue and organ donation that it is reasonable to take into account data obtained through studies of strategies to increase other types of donation. In Switzerland a recent recruitment strategy has established closer collaboration with the regional blood transfusion services, in order to learn from their experience with donation [2]. However, given the particularities of HSC donation, there are specific aspects to take into account in the ethical analysis. In order to be able to analyse whether consequences of different strategies to increase donation are acceptable, specific data concerning this type of donation are useful, and perhaps even necessary.

\section{Increasing efforts and resources to enlarge HSC banks}

Different types of HSC banks imply different types of risks related to donation as well as different types of costs to maintain the banks and registries and varying benefits for future recipients of the transplantable units. As far as risks to donors are concerned, unrelated umbilical cord blood banking [8] and banks that store stem cells derived from aborted foetuses, e.g. to obtain foetal liver HSC, have the advantage to imply a lower risk. Indeed, «a bank of fetal liver HSC will prove useful in treating a variety of genetic diseases before birth by in utero HSC transplantation» [9, p. 394]. In both cases, the stem cells are derived from sources such as the placenta or aborted foetuses that would have been thrown away in most cases, and there is no harm to the mother, her baby or the mother who underwent abortion. It would therefore seem straightforward from an ethical point of view to increase efforts in building these types of blood banks, while ensuring adequate informed consent of mothers [8, 9]. ${ }^{2}$

1 However, according to the Swiss Blood Stem Cell web page «Blood stem cells cannot be donated regularly but, if at all, usually only once or twice in a lifetime» [www.sbsc.ch/in-case-you-donate/ (accessed 2.4.2012)].

2 In Switzerland there are 2 public banks with which the SBSC works closely, 1 in Basel and 1 in Geneva, in which more than 3000 units are currently stored and made available to patients [2]. 
However, this solution has two major drawbacks. First, both types of banks contain a limited amount of material from the same donor. While for some indications, cord blood and foetal stem cells are particularly suitable, they are insufficient for other transplantation indications of HSC. ${ }^{3}$ In relation to this it is important to mention that in recent years there has been «a significant increase in and promising clinical results with 〈double-cord〉 transplants (transplants from 2 different cord blood donors) or even «multi-cord transplants for adults» [2, p. 306].

Second, costs for the establishment and maintenance of umbilical cord blood (CB) banks for unrelated donation are several times higher than the costs related to HSC donation of living children or adults, for example due to the necessity to store the blood and/or its products until a matching recipient is found which may take several years $[10,11] .{ }^{4}$ This raises the question, as to how much society should pay in order to increase the number of cord blood stem cell units and to permit the storage of stem cells obtained without significant risks to donors. Strategies to increase donation of placenta derived stem cells have been examined in Switzerland. ${ }^{5}$ The Swiss study showed «a high degree of satisfaction of unrelated umbilical CB donation for banking in women 6 months after delivery» [8, p. 604]. The main barriers for donation seemed to have been that in spite of a «well-performed and detailed informed consent procedure» a significant proportion of mothers remained concerned about improper use of the blood cells, mainly genetic testing or experimentation [8]. The data show that public education and adequate counselling of pregnant women and their partners are crucial to improve strategies to obtain more available stem cell units. It is worth noting that, the described strategies to increase this type of HSC donation are fully ethically acceptable if not ethically required, depending on the way how society balances the allocation of financial means for this type of banking in comparison to other health care interventions.

\section{Information of donors about benefits and risks of unrelated HSC donation}

During the past years, an increasing percentage of HSC have been obtained from peripheral blood (PB), while the percentage of stem cells taken directly from the bone marrow (BM) decreased proportionally [12]. For example, in Italy in 2008, 1467 allogeneic transplants were performed, of which 636 (43.4\%) were obtained from an unrelated donor, 188 from BM and 323 from PB [13]. The way in which HSC are obtained, as well as the way and type of information provided to donors about benefits and risks, is likely to influence a person's willingness to donate. While it is not controversial that voluntary and informed consent of donors is the ethical and legal prerequisite for donation in order to ensure that the donor's decision is free and not unduly coerced [14], it remains open to discussion how much information is adequate and how much choice donors should have. Should they be allowed to choose between BM or PB HSC donation because that might increase their motivation to donate? Or should donors rather be protected against bad choices that imply higher than necessary risks to them or to the recipients? BM donation has been carried out for more than 30 years and its risks are well known. It requires hospital admission for 1-3 days and absence from work is usually 7-10 days. Contrary to PB HSC harvesting, no administration of HSC stimulating drugs is necessary [13]. Data in the Cochrane Central Register have been obtained primarily from adults, and comprise 6 relevant randomised controlled trials that compared allogeneic BM and PB SC donations' safety. Both physical and psychological side effects of the two methods were reported [13]. While in the BM group there were overall more (56\%) adverse events observed than in the PB group (44\%), most of them were minor side effects such as pain at the surgical site and asthenia following anaesthesia. The data from the European Group for Blood and Marrow Transplantation analysis, performed 1993-2005, seem to indicate that BM donation is overall safer as far as serious side effects are concerned. Five fatal events were observed, of which one concerned a BM donor and the other four PB donors. Among the 37 reported serious adverse events only 12 took place after BM donation, compared to 24 that occurred in a $\mathrm{PB}$ donor $(\mathrm{P}<05)$ [13]. Some fear that G-CSF can theoretically increase the risk of haematological malignancies, however studies have not found evidence for that, but follow up has been short [15]. In the case of children the risks of short and long-term G-CSF administration are even less well established [15-17]. Risks vary across different subgroups of donors which confirm the «necessity of accurate attention to donor selection and evaluation in bone marrow donation» [13, p. 2192].

Up to now countries have reacted differently to the available evidence. In France, the donation of PB stem cells is forbidden for minors, because in vivo blood treatment before a donation is only allowed in adults. For the latter, age limits exist that vary according to relationship between donors and recipients. PB HSC donation in France is allowed for family members until the age of 60 , but for unrelated donors only until the age of 50. Unrelated donors may however give BM until the age of 60 [12]. According to Esperou [12], in Belgium PB HSC donation is allowed for minors who

3 Moreover, this type of HSC transplantation as Thomas Bart argues "has frequently become the 'last resource' because of the possibility of a higher mismatch due to the relative immaturity of its blood stem cells” [10, p. 141].

4 Other costs involved are those in relation to treating and typing [9].

5 The study required not only obstetric clinics to devote time and resources to systematic recruitment of donors, but relied to a notable extent on thorough information of donors and the public. 
donate to a sibling, in Canada it is also allowed for unrelated donation, but only the second time such donation takes place and not the first time. In Japan, only donation to a family member but not unrelated donation may be done using PB [12].

A number of conclusions can be made based on these data. First of all, since the benefit of unrelated donation depends to a great extent on international collaboration in order to find the best possible match, the variation between countries as to acceptable risks is likely to undermine the trust of donors and may have a negative impact on their willingness to donate. The first important step to increase donation would therefore be to harmonise recommendations and policies internationally. The SBSC database is required by law to report all «transplant outcomes and to adhere to the comprehensive quality management system JACIE (www.Jacie. org)» [18, p. 327]. The SBSC data registry, which unique feature is its capacity to capture $100 \%$ of all HSC transplant in Switzerland performed in public institutions, can be seen as a good international example for the establishment of good quality control mechanisms.

Second, since risks and benefits of BM and PB HSC donation are similar, although not identical, full and unbiased information of donors is likely to have the best effect in the long run to maintain their motivation. In the absence of significant negative consequences on the recipient following from the method of donation, it does not seem to exist any justified reason for paternalistic limitation of donors' choices, especially if this paternalism could have a negative influence on the willingness to donate. However, more studies are urgently needed to obtain more data on the effect of choice on motivation to donate HSC.

\section{Motivation enhancement strategies to donate, including prevention of last minute withdrawal of donors that puts at risk the life of the recipient}

A specific problem to unrelated HSC donation lies in the fact that a time gap exists between the first motivation to join a donor registry and the final decision to actually donate, usually only several years later. The World Marrow Donor Association's (WMDA) standards give precedence to the donors' right to withdrawal even if this might entail serious and even fatal consequences for the recipient [19].

Although the primary responsibility of the registry is in protecting the donor and ensuring their safety, the registry must ensure that the donor is aware of the serious, and potentially life-threatening, consequences to the recipient if the donor chooses to withdraw at any time, but particularly if this is after the recipient's pretransplant conditioning has commenced [see (20). p. 833].
Based on the donors' autonomy rights, the WMDA decided that it is ethically not acceptable to force donors in any way to reconsider the withdrawal by legal, economical, moral, emotional or other means. The donor must not be made legally responsible for any consequences her/his withdrawal has on the patient [21]. This balancing of donor's autonomy versus beneficence to the recipient can also be motivated by consequentialist reasons. It could increase donors' willingness to sign up for the donor process because they do not need to fear to be at any time forced into donation. The obligation to protect recipients is instead conferred to the donor registry. It is both the transplant centre and the donor registry that have the «responsibility to avoid a situation where a donor withdraws from the procedure at a critical time». In addition to this, to avoid detrimental withdrawal, the donor registry «should do whatever is possible to identify, as early as possible, problems or doubts that might interfere with the donor's ability to donate» [21, p. 226]. This implies that for uncertain donors early ways to opt out must be in place, where there is no loss of face.

The education process must be such that a donor cancellation, for any reason, is not disastrous or depressing, but rather easily understandable and acceptable to the donor [21, p. 226 (emphasis added)].

As long as there are no other available data, one has to assume that the highest number of donors and least withdrawals are not obtained through unethical pressure or persuasion, but through good communication, trust, and understanding [21], because this helps the donor to cope with possible later stressful events. In Switzerland a successful strategy to increase the number of donors has been the possibility for donors to register online [2]. The website www.bloodstemcells.ch was set up for this purpose. This motivation enhancement measures taken by Switzerland also include machine-readable forms and novel sampling methods that make the sampling less invasive and which allow donors to carry the blood sample collection at home. In a similar manner, new donors are «no longer tested for blood group and infection markers» [2, p. 303]. These are now only carried out if the person is invited for a compatibility test. While Switzerland has already shown a commitment with finding strategies to increase donation, we recommend that in order to keep with ethically correct motivation profiles it is necessary to provide donors with information and education that make them fully aware about their rights and any limitations (if any) of the procedures and therapies themselves. The main goal is to motivate donation decisions that are not based on feelings of obligation, but rather on a mature sense of responsibility built upon objective, nonbiased, and thorough information, including the fact that there is a reasonable possibility of multiple or subsequent donation requests. In this respect it 
seems a sensitive measure that the WMDA requires centres to document not only informed consent as such but to indicate in detail how the donor was counselled [21]. Or as it is case of Switzerland, the fact that donors are followed up after donation can also be seen as a motivation feature for individuals thinking about the possibility of becoming donors.

\section{Advertising}

Advertising is controversial because of different problems. It might use emotions to unduly pressure possible donors towards accepting to be in a registry and to donate. In addition, it is feared that donors who respond to emotionally loaded advertising are less reliable when it comes to actual donation than those that make the decision outside any emotional context. However, many donors are motivated by the knowledge of a more or less close person who suffered from serious disease requiring any form of transplantation. Also, without advertising referring to actual cases of patients, many possible donors might not even be aware of the stakes and not able to imagine the benefits HSC donation has for the life of patients.

Recently, a case from Spain has triggered much debate about the limits of advertising. In 2011, the Spanish National Transplant Organization (ONT) made a number of allegations concerning the activities of the German Bone Marrow Donor registry (Deutsche Knochenmarkspenderdatei, DKMS) in Spain [22]. ONT alleged that DKMS activities in Spain were illegal referring to recommendations given by the Spanish Commission for Transplants and Haematological Stem Cells. According to these recommendations, donors should preferably not be won by reference to a specific patient because such donors would be less reliable. In addition, the chance to find a matching donor for these specific patients would be too small. DKMS defends their practice by indication that the recommendations are not legally binding and that they have good reasons to contradict the allegations. They claim that their reasons are in line with international medical practice, for example WMDA standards, but also consistent with evidence based scientific literature [23]. The CEO of DKMS has defended its practice based on the data they have obtained during the past 20 years which «can prove in numbers that donors registered with reference to a specific patient are not less reliable than other donors; in fact, DKMS donors are by far the most reliable donors worldwide» [23, p. 2]. Through advertising using individual cases, therefore the sum of all donors who agree to register increases and «leads to a broadening of the general donor base» [23]. Moreover, DKMS argues that they inform all registered donors that they are not registered for only one patient but for all patients in need and that their advertising activities usually build on the strong engagement of patients and their families. An example is the case of Sabine Geisenhofer, the young mother of a one year-old child who advertised through youtube and online journals her need for a donor. As a result of the campaign, 1572 individuals agreed to HLA typing and to be registered for future donation. MS. Geisenhofer's child was finally transplanted using a donation found through worldwide connected registries as no match was found among the new HLA typed volunteers. However, it is worth noting that all the newly found potential donors agreed to donate to other patients in need if they were found not to be a suitable match for the S. Geisenhofer's child [24-26].

In conclusion, whether any specific form of advertising is acceptable or not, will depend on three major aspects. First, information provided must be correct and not hide any risks involved in donation. Second, there should not be any emotional pressure put on donors by the registry. On the other hand, patients and their families have the right to describe their own stories and to make them known publicly. Third, recruitment where donors learned about HSC donation through knowledge about a particular patient should be accompanied by research on the overall reliability of such donors.

\section{Unrelated donation limited to certain groups of recipients}

In Switzerland, too, the pressure is growing to find new HSC donors. Possible donors in Switzerland have indicated their concern to want to know who gets their stem cells. Such questions were integrated in a recent research project financed by the Swiss National Science Foundation. Does it matter to donors if patients are responsible for their illnesses? Can donors withdraw their donations in such cases? What happens if a donor has been assured that his donation will save small children but is actually used for a 70 year-old patient [27]?

While direct donation to a relative is a well-established practice to ensure optimal HLA matching, directed donation to non-related people has been discussed controversially [4, 28-31]. One argument against this practice is that donor protection is jeopardised because knowing the recipient might create pressure on the donor. It is also argued that incentives, such as payments, may be used by patients, usually in a clandestine way if they are illegal in the country. Another common argument is that allowing donors to limit their donation to a certain group of patients would also lead to unfair discrimination. Requests risk to be made based on racism, blaming of certain patient groups, or age related preference. Such discrimination of mostly vulnerable groups has a negative influence in society because it favours the acceptance of a discriminatory policy. It seems likely that in the end overall altruism in society could decrease with a negative effect on dona- 
tion altogether, apart from the fact that the administration of such selective donation requests risk to be an administrative nightmare creating significant additional costs. Apart from such consequentialist arguments, it must also be said that even if such selective donation were proven to increase the number of donations, it would be contrary to the prohibition of unfair discrimination which is part of the human rights framework strongly enshrined in modern societies.

It should be noted that the WMDA has concentrated its efforts on volunteer unrelated donors. «Donors must be willing to donate on behalf of any patient being treated in any part of the world» [20, p. 832]. Registration of a donor implies a general offer to be available for any patient in need of a haematopoietic stem cell transplant anywhere in the world, «irrespective of the patient's age, gender, nationality, creed or ethnicity» [19, p. 539]. Understandably, the best possible match can only be found, if all registries are internationally linked and donors available for any kind of patient in need, based only on HLA compatibility or other clinically relevant characteristics. The principle of non-selective donation is therefore accepted worldwide for unrelated HSC donation and regarded as an ethically acceptable practice. A separate issue is related to the principle of anonymity, a widely held position that aims to avoid abuse, such as donors asking for compensation after finding out to whom he or she donated their HSC. WMDA is concerned about possible pressures if the principle of anonymity is breached, thus, it recommends «that the donor center/registry should not inform a donor about the patients' diagnosis, gender, age, and similar kinds of facts» [21, p. 227]. In addition concerns exist that motivation of donation will decrease if the donor learns about possible negative outcomes of the donation, as they might feel that the pain and effort of the donation was 'wasted' [12]. General information about the prognosis of the patient may eventually be given, but only after a certain time and with great caution. Shaw and colleagues underline that registries must have a written policy listing the conditions under which donors and recipients might be informed of each other's identity [20]. Since it is not rare that donors will be asked for subsequent donations, it is important that registries adopt policies which guarantee that donors are not put under undue pressure because donor anonymity has been abandoned, perhaps even at the request of the donors themselves.

If it were true that in some parts of Switzerland a significant number of possible donors refuses donation because of fear that their HSC might be given to foreigners, old patients or other groups that they do not value in the same way as others, what would be the possible consequences? A likely consequence is that donor groups who donate only in a selective way, for example less altruistic countries as a whole, will also only receive transplants from the same selected groups, meaning from their own country, i.e. they will decrease their own chances to find a well-matched transplant. Such policies tend to be unfair overall since most complex groups are not homogenous and the 'punishment' would be unfair for those members of the countries who donate without limitations. Here again, an ethical way to deal with such claims is better information. The public must know about the necessity of international solidarity and societies should increase all efforts against in-country racism and unfair discrimination.

\section{Payment for donation}

WMDA Standards are adamant that donors «must not be paid for their donation, but may be reimbursed for expenses incurred during the donation process, for example, time lost from work or travel to the collection center» [20, p. 832]. The reasons for such a policy are generally based on a consequentialist approach and most data available about the consequences of payments stem from studies about blood donation. Already in the 1970 the famous study of Titmuss [32, 33] presented data indicating that payment is likely to 〈wash out altruistic motivation and therefore overall to decrease donation frequency as well as the quality of the donated blood. Similar evidence comes from several additional studies [7, 34, 35] which speak in favour of perverse effects of financial rewards and motivated the World Health Organization (WHO) to recommend that all blood donations should come from unpaid voluntary donors [7].

While the international position on payment has in general joined the WHO recommendations, offering reimbursement of costs to donors for travel and lost work time, some countries are offering payment to blood donors [7]. We defend the position that payment should only be offered as part of randomised studies that intend to obtain more evidence of the consequences of payment on the donation of HSC. Unless strong evidence indicates clear benefit of payment on willingness and reliability to donate HSC, there is no justification today to use monetary benefits in this field. Hence, based on current evidence, it is ethically the best option to forgo monetary benefits because of the overall benefits such policy has for recipients.

\section{Creating additional non-monetary benefits}

Donation can be due to intrinsic motivation, the socalled pure altruism, or due to extrinsic motivation which includes an inner 〈warm-glow〉 or moral satisfaction. A recent study involving a large sample representative of 15 European countries showed that the results «are consistent with the idea that altruistic behaviour can be incentivised as long as the rewards do not conceal the identity of the blood giver as a donor» [7, p. 2], meaning as long as donors do not feel 〈paid〉. Accord- 
ing to this study, as well as other findings from behavioural economics [14], providing non-monetary benefits to possible donors of HSC will maintain altruistic motivation while at the same time increasing frequency of donation. Buyx [14] reminds us that these findings are not new, nor really surprising. What she finds surprising is that these findings «have not been put to use systematically to help increase ... donation» $[14$, p. 335]. Several effects are known to influence human choices such as the framing effect which means the way in which options are presented, the conformity effect, which indicates that independent from rational reasoning, «people have an in-built, automatic desire to behave in the way others behave» [14, p. 335] and the incentives effect. Incentives will influence people's choices if they are tailored to people's motives and combined with framing or information about what others do. Such measures are effective without being coercive [14]. It is perfectly justified for donor centres to use insights into behavioural psychology to affect decisions - without this meaning that one makes people agree to donation against their will. Incentives might be necessary throughout the entire time a donor is in the registry. This requires regular, for example annual contacting of donors and which also provides the opportunity for donors to maintain or reconsider their motivation in advance which in turn increases their reliability. Among ethically acceptable incentives that have been discussed depending on the group that is addressed are vouchers for songs on iTunes, for a wellness class or a restaurant; mobile phone ring tones or mobile phone credits; video game bonuses; tickets to the theatre, museums, lectures; a mark of public recognition (e.g. donors' names being put on public display on $\mathrm{TV}$, online, in a newspaper, read out in a radio show or at some community event); donor-exclusive T-shirts or events to which only donors can buy tickets or can buy them first [14].

\section{Conclusions: ethical ways to increase HSC donation}

There is an urgent need to increase HSC donation. Not all strategies to increase donation are acceptable. Existing empirical data on motivation need to be better applied to the practice of HSC donation. We have shown that deontological arguments referring to the respect for donor autonomy as well as consequentialist arguments based on data about benefits and risks of certain strategies lead in most cases to the same conclusions. Advertising is ethically acceptable as long as certain conditions are maintained. This includes that advertising with reference to individual receivers is acceptable under certain circumstances. The donor must be made fully aware of the favourable and adverse outcomes of HSC donation. Unbiased and complete information about risks and benefits is likely to increase the frequency, reliability and quality of donations. Donor and patient privacy should be maintained and selective donation should be excluded or limited. Providing monetary benefits for donation, outside justified reimbursements, would increase social injustice and probably decrease safety; however some other forms of non-monetary 'reward' are acceptable and so far underused.

A balance needs to be made between safety, efficiency and costs of different forms of HSC donations. The best way to increase donation is not through pressure, but through transparency and best information and advocates of donors. Last but not least, in order to be able to conclude in a stronger way on the ethical aspects of different strategies to increase donation, more empirical research on the consequences of such strategies is needed.

Conflict of interest: None to declare

\section{Zusammenfassung}

Ethisch vertretbare Möglichkeiten, die Spendebereitschaft für Blutstammzellen zu erhöhen

Ethische Aspekte des Umgangs mit Spenden von menschlichem biologischem Material werden seit langer Zeit diskutiert, angefangen bei der Organspende bis hin zur Gewebe- und Zellspende. In diesem Zusammenhang ist eine zentrale ethische Frage, wie die Spendebereitschaft auf sichere und ethisch vertretbare Weise erhöht werden könnte. In diesem Beitrag konzentrieren wir uns auf die Frage, wie die Bereitschaft zur nichtverwandtschaftlichen Spende von Blutstammzellen auf ethisch vertretbare Weise erhöht werden könnte, wobei Fragen der spezifischen Information über Nutzen und Risiken sowie nichtmonetäre Vorteile im Vordergrund stehen. Darüber hinaus fragen wir, ob bestehende Praktiken zur Erhöhung der Spendebereitschaft, beispielsweise der Einsatz für bestimmte Typen von Blutstammzellenbanken, Bezahlung, Werbung und gezielte Spenden, ethisch vertretbar sind oder nicht. Schliesslich formulieren wir einige Empfehlungen, um einerseits die Debatte in dieser Frage voranzubringen und andererseits die ethisch vertretbaren Praktiken der Blutstammzellenspende in der Schweiz zu fördern, wobei diese Empfehlungen durchaus auch weltweit angewendet werden können.

\section{Résumé}

Des méthodes éthiquement acceptables pour augmenter les dons de cellules souches hématopoïétiques

Les enjeux éthiques du don de matériel biologique humain - du don d'organes au don de tissus et de 
cellules - sont discutés depuis longtemps. Un des soucis soulevés dans ce contexte est l'identification de méthodes sûres et éthiquement acceptables d'augmenter ce type de dons. Dans cet article, nous abordons quelques méthodes éthiquement justifiées d'augmenter le don non apparenté de cellules souches hématopoïétiques, comme l'information sur mesure sur les risques et bénéfices, et les bénéfices non financiers. Nous discutons également les aspects éthiques de pratiques actuelles comme l'investissement d'efforts et de ressources dans certains types de banques cellulaires, la publicité et le don dirigé. Nous concluons avec quelques recommandations susceptibles de faire avancer le débat dans ce domaine, et nous soutenons des pratiques éthiquement justifiées dans le domaine du don de cellules souches hématopoïétiques en Suisse, qui pourraient également être employées à l'échelle mondiale.

\section{Correspondence \\ Bernice Elger, Laura Cabrera \\ Institut für Bio- und Medizinethik \\ Universität Basel \\ Missionsstr. 24 \\ $\mathrm{CH}-4055$ Basel}

E-Mail: b.elger[at]unibas.ch, laura.cabrera[at]unibas.ch

Manuscript submitted: 10.4 .2012

Revisions submitted: 22.7.2012

Accepted: 25.7.2012

\section{References}

1. Boo M, van Walraven SM, Chapman J, Lindberg B, Schmidt AH, Shaw BE, et al. Remuneration of hematopoietic stem cell donors: principles and perspective of the World Marrow Donor Association. Blood. 2011;117(1):21-5

2. de Faveri GN, Schwabe R, Bart T. Swiss Blood Stem Cells: More than Just a Registry. Transfusion medicine and hemotherapy: offizielles Organ der Deutschen Gesellschaft fur Transfusionsmedizin und Immunhamatologie. 2011;38(5):300-7.

3. Bone Marrow Donors Worldwide Online; http://www.bmdw.org/ (accessed 02.4.2012). [database on the Internet]. 2012.

4. Romagnoli S, Bart T, Buerkli P, Halter J. Considérations éthiques et juridiques sur les modalités du don dans la transplantation. Jusletter. 2011;29

5. Jennifer P. HSCT: The experiences of registries and future needs (OneMatch, Canada). Mastering the legal and ethical challenges of present and future cell donation; 29 March 2012; Landsitz Castelen, August, Switzerland.2012

6. Gratwohl A, Schwendener A, Baldomero H, Gratwohl M, Apperley $\mathrm{J}$, Niederwieser D, et al. Changes in the use of hematopoietic stem cell transplantation: a model for diffusion of medical technology. Haematologica 2010;95:637-43.

7. Costa-i-Font J, Jofre-Bonet M, Yen ST. Not all incentives wash out the warm glow: the case of blood donation revisited. CESifo working paper, no. 3527. CESifo Group, Munich, Germany: available at: http://eprints.lse.ac.uk/37538/ (accessed 20.3.2012). 2011.

8. Danzer E, Holzgreve W, Troeger C, Kostka U, Steimann S, Bitzer J, et al. Attitudes of Swiss mothers toward unrelated umbilical cord blood banking 6 months after donation. Transfusion. 2003;43(5) $604-8$

9. Mychaliska GB, Muench MO, Rice HE, Leavitt AD, Cruz J, Harrison MR. The biology and ethics of banking fetal liver hematopoietic stem cells for in utero transplantation. J Pediatr Surg. 1998;33(2): 394-9.

10. Bart T. Cost effectiveness of cord blood versus bone marrow and peripheral blood stem cells. ClinicoEconomics and outcomes research: CEOR. 2010;2:141-7.
11. Swiss Blood Stem Cell. In case you donate-Collection Procedure. Available at: http://www.sbsc.ch/en/in-case-you-donate/collectionprocedure/\#anker39 (accessed 02.4.2012). 2012.

12. Esperou H. [Ethics of stem cell donation in Europe]. Transfus Clin Biol. 2005;12(5):370-3. L'ethique du don de cellules souches hematopoietiques en Europe.

13. Bosi A, Bartolozzi B. Safety of bone marrow stem cell donation: a review. Transplant Proc. 2010;42(6):2192-4.

14. Buyx AM. Blood Donation, Payment, and Non-Cash Incentives: Classical Questions Drawing Renewed Interest. Transfusion medicine and hemotherapy: offizielles Organ der Deutschen Gesellschaft fur Transfusionsmedizin und Immunhamatologie. 2009;36(5): 329-39

15. Pentz RD, Haight AE, Noll RB, Barfield R, Pelletier W, Davies S, et al. The ethical justification for minor sibling bone marrow donation: a case study. Oncologist. 2008;13(2):148-51.

16. Pulsipher MA, Chitphakdithai P, Miller JP, Logan BR, King RJ, Rizzo JD, et al. Adverse events among 2408 unrelated donors of peripheral blood stem cells: results of a prospective trial from the National Marrow Donor Program. Blood. 2009;113(15):3604-11.

17. Pulsipher MA, Nagler A, Iannone R, Nelson RM. Weighing the risks of G-CSF administration, leukopheresis, and standard marrow harvest: ethical and safety considerations for normal pediatric hematopoietic cell donors. Pediatr Blood Cancer. 2006;46(4):422-33.

18. Passweg J, Baldomero H, Stern M, Bargetzi M, Ghielmini M, Leibundgut $\mathrm{K}$, et al. Haematopoietic stem cell transplantation in Switzerland: a comprehensive quality control report on centre effect. Swiss medical weekly. 2010;140(23-24):326-34.

19. Rosenmayr A, Hartwell L, Egeland T. Informed consent-suggested procedures for informed consent for unrelated haematopoietic stem cell donors at various stages of recruitment, donor evaluation, and donor workup. Bone Marrow Transplant. 2003;31(7):539-45.

20. Shaw BE, Ball L, Beksac M, Bengtsson M, Confer D, Diler S, et al. Donor safety: the role of the WMDA in ensuring the safety of volunteer unrelated donors: clinical and ethical considerations. Bone Marrow Transplant. 2010;45(5):832-8.

21. Bakken R, van Walraven AM, Egeland T. Donor commitment and patient needs. Bone Marrow Transplant. 2004;33(2):225-30.

22. Sanmartin OR, Alvarez RJ. Sanidad cambiará la ley para que DKMS no pueda actuar en España. El Mundo. 2012;18.1.2012:18

23. Winter SF. Rectification Concerning the Allegations made by the Spanish National Transplant Organization (ONT) Towards DKMS' Activities in Spain: http://www.dkms.es/pdf/TX_111201_MS_ Rectification_Englisch_final.pdf (accessed 20.3.12). 2011.

24. Merkur Online. Knochenmarkspender gesucht; 17.8.09: http:// www.merkur-online.de/lokales/landkreis-dachau/knochenmark spender-gesucht-444885.html (accessed 22.3.2012). 2009.

25. Merkur Online. Passender Spender für Sabine; 28.9.2009: http:// www.merkur-online.de/lokales/landkreis-dachau/passender-spen der-sabine-479099.html (accessed 22.3.2012). 2009.

26. Donaukurier.de. Sabine Geisenhofer verliert Kampf gegen Leukämie; 10.6.2010: http://www.donaukurier.de/lokales/kurzmeldun gen/pfaffenhofen/Sabine-Geisenhofer-verliert-Kampf-gegen-Leu kaemie;art74363,2287392 (accessed 22.3.2012). 2010.

27. Halter J. Legal and ethical challenges of stem cell donation. http:// www.nfp63.ch/E/projects/Pages/stem-cell-donation.aspx (accessed 30.3.2012). 2012

28. Ankeny RA. The moral status of preferences for directed donation: who should decide who gets transplantable organs? Cambridge quarterly of healthcare ethics: the international journal of healthcare ethics committees. 2001;10(4):387-98

29. Hilhorst MT. Directed altruistic living organ donation: partial but not unfair. Ethical theory and moral practice: an international forum. 2005;8(1-2):197-215.

30. Spital A. Must kidney donation by living strangers be nondirected? Transplantation. 2001;72(5):966

31. Truog RD. The ethics of organ donation by living donors. The New England journal of medicine. 2005;353(5):444-6.

32. Titmuss RM. The Gift Relationship. London: Allen and Unwin; 1970

33. Titmuss RM. The Gift Relationship: From Human Blood to Social Policy. New York: Vintage; 1971

34. Thorne ED. The common property nature of market-inalinability. In: Gerard-Varet L-A, Kolm S-C, Mercier Ythier J, editors. The Economics of Reciprocity, Giving and Altruism International Association Series. New York: McMillan; 2000 p. 47-77.

35. Andreoni J. Impure altruism and donation of public goods: a theory of warm glow living. Economic Journal. 1990;100(401):464-77. 